\title{
Hypercapnia-induced cerebral oedema in a patient with COPD exacerbation: a rare and under- recognised entity
}

\author{
Siddique Chaudhary, ${ }_{1}^{1}$ Ahsan Wahab, ${ }^{1}$ Shiny Varghese, ${ }^{2}$ Susan Jane Smith ${ }^{3}$
}

'Department of Internal Medicine, McLaren Regional Medical Center, Flint, Michigan, USA

${ }^{2}$ Department of Internal Medicine, McLaren Regional Medical Center, Flint, Michigan, USA

${ }^{3}$ Department of Internal Medicine, McLaren-Flint Health Care Center/Michigan State University, Flint, Michigan, USA

\section{Correspondence to}

Dr Ahsan Wahab,

aanish00@yahoo.com

Accepted 2 August 2017

\section{(a) CrossMark}

To cite: Chaudhary $S_{\text {, }}$ Wahab A, Varghese S, et al. BMJ Case Rep Published Online First: [please include Day Month Year]. doi:10.1136/bcr-2017221568

\section{DESCRIPTION}

A 56-year-old Caucasian woman with severe chronic obstructive pulmonary disease (COPD) on home oxygen presented with a severe exacerbation. Vitals included a blood pressure of $111 / 73 \mathrm{~mm} \mathrm{Hg}$, a pulse of $102 /$ minute, respiratory rate of $13 /$ minute and $\mathrm{O}_{2}$ saturation of $84 \%$ on oxygen of $2-3 \mathrm{~L} /$ minute by nasal cannula. She was lethargic, confused and was wheezing. She was placed on bi-level positive airway pressure (BiPAP) but her mentation continued to deteriorate. White cell counts were normal. Chest $\mathrm{X}$-ray showed hyperinflated lungs but no infiltrates. Arterial blood gases revealed severe hypercapnic respiratory acidosis with a $\mathrm{pH}$ of $7.26, \mathrm{pCO}_{2}$ of $100.1 \mathrm{~mm} \mathrm{Hg}, \mathrm{pO}_{2}$ of $187 \mathrm{~mm} \mathrm{Hg}$ and bicarbonate of $47 \mathrm{mmol} / \mathrm{L}$. In spite of BiPAP, her acidosis worsened with a $\mathrm{pCO}_{2}$ of $131 \mathrm{~mm} \mathrm{Hg}$. She was intubated for acute hypercapnic respiratory failure. Although her deteriorating mentation correlated with $\mathrm{CO}_{2}$ narcosis, it was judicious to perform neuroimaging like cerebral CT to rule out other causes of acute mental decompensation, particularly cerebrovascular accidents. Given this context, a CT of the head without contrast was performed which was negative for haemorrhage or ischaemia but revealed effacement of sulci, hypodense white matter, and vastly decreased size of lateral ventricles and basal cisterns consistent with cerebral oedema

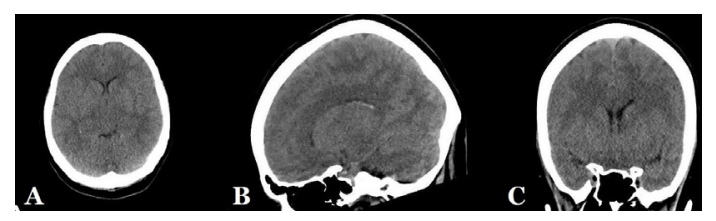

Figure 1 CT head without contrast (A) axial view (B) sagittal view (C) coronal view showing effacement of sulci, hypodense white matter, loss of grey-white matter junction differentiation, decreased size of lateral ventricles and basal cisterns consistent with cerebral oedema in the presence of hypercapnic respiratory failure.

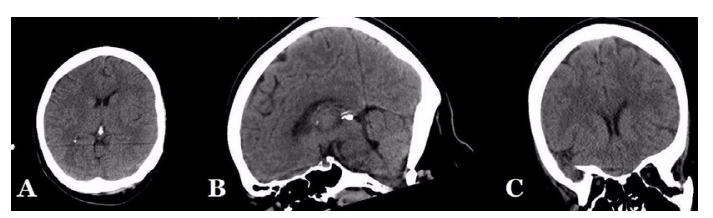

Figure 2 CT head without contrast (A) axial view (B) sagittal view $(C)$ coronal view showing a near-complete recovery of cerebral oedema after the resolution of hypercapnia and improvement of respiratory failure.

\section{Learning points}

- While cerebral perfusion varies optimally physiologically, an extreme variation in pathological states, like trauma, stroke, infection and hypercapnia, can lead to cerebral oedema. $^{1}$

- Patients with chronic obstructive pulmonary disease can have a dual mechanism of cerebral hyperperfusion including hypercapnia and hypoxia which can lead to cerebral oedema with features suggestive of raised intracranial pressure (nausea, vomiting, drowsiness, confusion, pupillary dilation, papilloedema, stupor and coma) in addition to changes in respiratory status. $^{12}$

- Imaging including CT, MRI, positron emission tomography and transcranial Doppler can help in cerebral perfusion assessment and can exclude other causes of altered mentation like haemorrhage or ischaemia. ${ }^{2}$ Treatment in such cases requires correction of the underlying pathology and resolution of hypercapnia, sometimes requiring intubation. ${ }^{3}$

- Although, hypercapnia-induced cerebral hyperperfusion is well known, hypercapniainduced cerebral oedema remains an underrecognised entity and hence should be considered in the absence of other causes of raised intracranial pressure.

- The treatment of this entity should focus on the underlying pathophysiology and hence on hypercapnia as the main cause of hyperperfusion and cerebral oedema.

(figure 1). She received usual treatment for COPD exacerbation including steroids and antibiotics. The following day her $\mathrm{pCO}_{2}$ was $78 \mathrm{~mm} \mathrm{Hg}$ with corresponding improvement in her cerebral oedema on CT (figure 2). Mental status continued to improve and she was extubated after 2 days.

Contributors $S C$ is the primary author who had initially written the preliminary rough draft of the image and then did primary data gathering; the accuracy of the data was checked and confirmed with the intensivist. AW collected information upon imaging and description of the neuroimaging and probed the findings further. He also rewrote the case and gave it the final shape. SV did the literature search and revised the whole article. SIS checked the language aspect of the case and made sure that the information is accurate and understable. She gave the final shape to the article.

Competing interests None declared. 
Patient consent Obtained.

Provenance and peer review Not commissioned; externally peer reviewed.

(c) BMJ Publishing Group Ltd (unless otherwise stated in the text of the article) 2017. All rights reserved. No commercial use is permitted unless otherwise expressly granted.

\section{REFERENCES}

1 Raichle ME, Plum F. Hyperventilation and cerebral blood flow. Stroke 1972;3:566-75.

2 Pollock JM, Deibler AR, Whitlow CT, et al. Hypercapnia-induced cerebral hyperperfusion: an underrecognized clinical entity. AJNR Am J Neuroradio/ 2009;30:378-85.

3 Joyce RR, McGee WT. Hypercapnic cerebral edema presenting in a woman with asthma: a case report. J Med Case Rep 2011;5:192.

Copyright 2017 BMJ Publishing Group. All rights reserved. For permission to reuse any of this content visit

http://group.bmj.com/group/rights-licensing/permissions.

BMJ Case Report Fellows may re-use this article for personal use and teaching without any further permission.

Become a Fellow of BMJ Case Reports today and you can:

- Submit as many cases as you like

- Enjoy fast sympathetic peer review and rapid publication of accepted articles

- Access all the published articles

- Re-use any of the published material for personal use and teaching without further permission

For information on Institutional Fellowships contact consortiasales@bmjgroup.com

Visit casereports.bmj.com for more articles like this and to become a Fellow 